\title{
Cross Sensitivity of Skin Rashes with Antiepileptic Drugs
}

\author{
Chris Hyson and Mark Sadler
}

\begin{abstract}
Background: Skin rashes are a well known complication of antiepileptic drug (AED) treatment. It has also been recognized that some patients will develop rashes from multiple AEDs (cross sensitivity). There are very few studies that have attempted to determine the frequency of cross sensitivity among AEDs. Methods: Charts of all patients attending an epilepsy outpatient clinic were reviewed to determine AED exposure and the occurrence of a rash from AEDs. Results: 633 patients had 1,875 exposures to 14 AEDs. Rashes occurred from carbamazepine $(N=27)$, phenytoin $(N=21)$, phenobarbital $(\mathrm{N}=5)$ and lamotrigine $(\mathrm{N}=1)$. A rash from 2 or more AEDs occurred in 14 patients and involved predominantly carbamazepine and phenytoin. Among the patients exposed to both phenytoin and carbamazepine $10 / 17(58 \%)$ of patients with a rash from phenytoin also had a rash from carbamazepine; conversely $10 / 25(40 \%)$ patients with a carbamazepine rash also had a rash from phenytoin. $4 / 5$ patients with a phenobarbital rash were sensitive to carbamazepine and/or phenytoin. Amongst the other most commonly used AEDs no rashes occurred from valproic acid or clobazam. Conclusions: The cross sensitivity rate for rashes involving carbamazepine and phenytoin is $40-58 \%$. If a rash develops from either of these AEDs, valproate or clobazam are safe alternatives.
\end{abstract}

\begin{abstract}
RÉSUMÉ: Érythèmes cutanés dus à une sensibilité croisée à des antiépileptiques. Introduction: Les érythèmes cutanés sont une complication bien connue de la médication antiépileptique (MAE). Il est également connu que certains patients développeront des érythèmes avec plusieurs MAEs (sensibilité croisée). ll y a très peu d'études qui ont tenté de déterminer la fréquence de réactivité croisée parmi les MAEs. Méthodes: Les dossiers de tous les patients d'une clinique externe d'épilepsie ont été révisés pour déterminer l'exposition aux MAEs et la fréquence d'un érythème dû aux MAEs. Résultats: 633 patients ont eu 1,875 expositions à 14 MAEs. Un érythème est survenu avec la carbamazépine chez 27 , avec la phénytö̈ne chez 21 , avec le phénobarbital chez 5 et avec la lamotrigine chez 1. Un érythème est survenu avec 2 MAEs ou plus chez 14 patients et impliquait surtout la carbamazépine et la phénytoïne. Parmi les patients exposés à la phénytoïne et à la carbamazépine, 10 sur 17 patients (58\%) ayant présenté un érythème dû à la phénytoïne ont également eu un érythème dû à la carbamazépine; à l'inverse, 10 des 25 patients (40\%) ayant présenté un érythème dû à la carbamazépine ont également eu un érythème dû à la phénytoïne. 4 patients sur 5 qui avaient présenté un érythème dû au phénobarbital étaient sensibles à la carbamazépine et/ou à la phénytoïne. Aucun érythème n'est survenu avec les autres MAEs les plus fréquemment utilisés, soit l'acide valproïque et le clobazam. Conclusions: Pour les érythèmes impliquant la carbamazépine et la phénytoïne, le taux de sensibilité croisée est de 40 à $58 \%$. S'il survient un érythème dû à l'un ou l'autre de ces MAEs, le valproate ou le clobazam sont des alternatives sécuritaires.
\end{abstract}

Can. J. Neurol. Sci. 1997; 24: 245-249

Adverse cutaneous reactions from antiepileptic drugs (AEDs) are familiar to clinicians treating epilepsy. The reported frequency of skin rash ranges from $2 \%-13 \%$ for phenytoin, carbamazepine and phenobarbital. ${ }^{1-7}$ Rashes from valproic acid are extremely unusual. ${ }^{2,6,8}$

The clinical expression of drug sensitivity ranges from a mild macular rash to a severe life threatening illness with multiorgan involvement (a generalized hypersensitivity syndrome).$^{9}$ All of these reactions typically begin 2-8 weeks from the onset of therapy. ${ }^{9,10}$ Fortunately, the majority of reactions are mild but the hypersensitivity syndrome may begin as a benign appearing skin eruption.

Cross sensitivity (the occurrence of rash in response to sequential exposure to more than one AED) has been previously described. ${ }^{9.10,12-16}$ In a recent review paper of severe cutaneous reactions to drugs, Roujeau and Stern commented that "cross sensitivity between the various aromatic antiepileptic drugs is well documented, making it difficult to select alternative anticonvulsant therapy." ities exist, there is a surprising paucity of data in the literature to indicate how often cross reactions occur and which AEDs are responsible. This retrospective review was conducted to a)

From the Dalhousie University Medical School (C.H.) and the Division of Neurology, Queen Elizabeth II Health Sciences Centre (M.S.), Halifax.

RECEIVED NOVEMBER 20, 1996. ACCEPTED IN FINAL FORM FEBRUARY 25, 1997.

Print requests to: Mark Sadler, Room 3829, Queen Elizabeth II Health Sciences Centre, 1796 Summer Street, Halifax, Nova Scotia, Canada B3H 3A7 
responsible. This retrospective review was conducted to a) examine the frequency of AED cross sensitivity and, b) determine what might be a reasonable alternative AED when a rash occurs.

\section{METHODS}

We reviewed the medical records of all patients attending a tertiary care adult outpatient epilepsy clinic between July 1988 March 1994.

The drug and patient inclusion/exclusion criterion were defined before the chart review. We included all patients who had been exposed to any AED; a diagnosis of epilepsy was not essential. A routine component of the initial consultation in this clinic is an assessment of all prior AED exposures and reasons why medications were stopped. A list was constructed of all AEDs taken by each patient. Most AED rashes begin within 6 weeks; 9,10 consequently we did not include a drug as an "exposure" if it was taken for less than 6 weeks and stopped for any reason other than a rash. A "rash" was defined as any cutaneous eruption that occurred within 6 weeks after starting an AED and caused the drug to be discontinued.

Prior to the chart review we elected to exclude patients with a history of rash in whom we could not be reasonably confident that a particular AED was the offending agent. We excluded patients who: a) experienced a rash when more than one AED was started at the same time, b) developed a rash more than 6 weeks after starting a drug, or c) had a cutaneous eruption within 6 weeks of starting an AED and concurrent treatment with other drugs commonly associated with rashes (e.g., antibiotics).

"Cross sensitivity" was defined as the occurrence of a rash from an AED in patients who have previously experienced a rash on exposure to a different AED.

Odds ratios and confidence limits were calculated with Epi Info."

\section{RESULTS}

We reviewed 634 charts. One patient with a chronic dermatitis and an exacerbation within 6 weeks of starting phenytoin was excluded. Three AED "exposures" were excluded; all involved primidone (stopped within 1 week because of excessive sedation).

The 633 remaining patients had 1,875 exposures to 14 AEDs; 39 patients $(6.1 \%$; $95 \%$ confidence interval $=4.3 \%-8.1 \%)$ experienced at least 1 rash from at least 1 drug. The frequency of rash from individual AEDs is described in Table 1.

Carbamazepine was approximately 2.5 times more likely to cause a rash than phenobarbital (odds ratio $=2.49 ; 95 \%$ confidence interval $=0.93-8.40$ ). Similar results were obtained for phenytoin compared to phenobarbital (odds ratio $1.91 ; 95 \%$ confidence interval $=0.69-6.56$ ). Amongst the other most commonly used AEDs no rashes occurred from exposure to valproate, the benzodiazepines, or primidone.

Table 2 summarizes the patients with rashes and their AED exposures. There were 34 patients who had a cutaneous eruption alone and 4 patients with a rash plus other manifestations of systemic involvement.

A rash from 2 or more AEDs ( cross sensitivity) occurred in

\begin{tabular}{lll}
\hline Table 1: Antiepileptic Drug Exposures and Rashes. \\
\hline Drug & $\begin{array}{l}\text { Number of } \\
\text { patients exposed }\end{array}$ & $\begin{array}{l}\text { Number of rashes } \\
(\%)\end{array}$ \\
\hline phenytoin & 470 & $21(4.5)$ \\
\hline carbamazepine & 469 & $27(5.7)$ \\
\hline valproic acid & 268 & 0 \\
\hline phenobarbital & 209 & $5(2.4)$ \\
\hline clobazam & 195 & 0 \\
\hline primidone & 128 & 0 \\
\hline clonazepam & 44 & 0 \\
\hline ethosuximide & 34 & 0 \\
\hline nitrazepam & 19 & 0 \\
\hline lamotrigine & 17 & $1(5.9)$ \\
\hline methsuximide & 11 & 0 \\
\hline vigabatrin & 9 & 0 \\
\hline gabapentin & 1 & 0 \\
\hline trimethadione & 1 & 0 \\
\hline
\end{tabular}

14 subjects (patients $7,10,12,15,16,20,25,26,28,29,31-34$ ). The reactions in individual patients were the same variety (either rash only or rash plus) in all instances of cross reactions. Cross sensitivity occurred predominantly with phenytoin and carbamazepine. Among patients exposed to both phenytoin and carbamazepine, rashes occurred in 17 patients from phenytoin and 25 from carbamazepine. Ten patients developed rashes with exposure to each of these AEDs. Therefore, 10/17 (58\%) of patients with a rash from phenytoin had a rash from carbamazepine and $10 / 25(40 \%)$ of patients with a carbamazepine rash also developed a rash with phenytoin.

The number of rashes and cross sensitivities with other AEDs was small. However, $4 / 5$ patients with a rash from phenobarbital also had rashes from either carbamazepine or phenytoin. Of the 38 patients with rashes from carbamazepine, phenytoin, or phenobarbital 24 received valproate and 12 took clobazam without difficulty. The single patient with a lamotrigine rash did not have a rash from phenytoin, carbamazapine or phenobarbital.

\section{Discussion}

The ideal method to determine the exact frequency of cross reactions among AEDs would be a prospective evaluation. However, the relatively low rash frequency $(6.1 \%$ of patients in our study and $2-13 \%$ of patients in the literature $\left.{ }^{1-7}\right)$ plus the fact that not all patients are exposed to multiple AEDs make such a study impractical. The tertiary care nature of our clinic population provided a reasonable number of patients $(\mathrm{N}=633)$ with often difficult to control seizures and therefore a substantial number of AED exposures $(\mathrm{N}=1,875)$.

We believe our retrospective study provides an estimate of the frequency of AED induced rashes and cross reactions. It is impossible to be certain that all rashes in the clinic population were a result of AED exposure; rashes have been reported in the placebo arm of some AED trials and not all rashes are drug induced. 
Table 2: Patients with rashes and other sensitivity reactions.

\begin{tabular}{|c|c|c|c|c|c|c|c|c|c|c|}
\hline \multirow[t]{2}{*}{$\overline{\text { Patient }}$} & \multicolumn{7}{|c|}{$\begin{array}{c}\text { Antiepileptic Drug Exposure } \\
\left(+=\text { exposed to drug; }{ }^{*}=\text { reaction to drug) }\right.\end{array}$} & \multirow[t]{2}{*}{ Rash only } & \multirow[t]{2}{*}{ Rash Plus } & \multirow[t]{2}{*}{ Comment } \\
\hline & $\overline{\text { PHT }}$ & CBZ & $\mathbf{P b}$ & PRM & VPA & CLB & $\overline{\text { OTHER }}$ & & & \\
\hline 2 & $+^{*}$ & & & + & & & & + & & rash at 5 days \\
\hline 3 & + & $+*$ & & + & & & & + & & rash at 5 days \\
\hline 5 & + & $+*$ & & & & + & & + & & $\begin{array}{l}\text { rash on } 2 \text { exposures to } \\
\text { cbz; 1st after } 7 \text { days; } \\
\text { 2nd after } 14 \text { days }\end{array}$ \\
\hline 6 & + & $t^{*}$ & & & + & & & + & & rash at 3 weeks \\
\hline 7 & & + & $+*$ & & + & & & & $\begin{array}{l}\text { fever, elevated liver } \\
\text { enzymes }\end{array}$ & both reactions at $<1$ week \\
\hline 11 & & + & $+*$ & & & & & + & & \\
\hline 12 & $+*$ & $+*$ & & + & & & & + & & \\
\hline 13 & $+*$ & + & & + & + & & $\begin{array}{l}\text { methsuximide } \\
\text { nitrazepam }\end{array}$ & + & & \\
\hline 14 & + & $t^{*}$ & & & & & & + & & rash at 3 weeks \\
\hline 15 & $+*$ & $+*$ & & & + & + & & + & & \\
\hline 16 & $+*$ & $+*$ & & & + & + & & + & & \\
\hline 17 & $+*$ & & & & + & + & & + & & \\
\hline 18 & & $+*$ & & & + & & & + & & rash at 3 weeks \\
\hline 19 & $+*$ & + & & & + & & & & & rash at 10 days \\
\hline 25 & $+^{*}$ & $+*$ & & & + & & & + & & pht, cbz rash at $7-10$ days \\
\hline 26 & $+*$ & $+*$ & & & & + & & + & & pht, cbz rash at 7-10 days \\
\hline 27 & + & $+*$ & & & & + & vigabatrin & + & & \\
\hline 28 & $+*$ & $+*$ & $+*$ & & & & & + & & rashes at 2-3 weeks for each \\
\hline 29 & $+*$ & $+*$ & + & & + & & clonazepam & + & & pht, cbz rash at $10-14$ days \\
\hline 30 & + & $+*$ & & & + & & & + & & \\
\hline 31 & $+*$ & $+*$ & & & + & & & + & & $\begin{array}{l}\text { cbz rash at } 3 \text { weeks; pht rash } \\
\text { at } 1 \text { day }\end{array}$ \\
\hline 32 & $+*$ & $+*$ & + & & + & & & + & & $\begin{array}{l}\text { pht induced diffuse urticaria at } 4 \\
\text { weeks; cbz urticaria at } 1 \text { week }\end{array}$ \\
\hline 33 & & $+*$ & $+*$ & & + & & & & $\begin{array}{l}\text { lymphadenopathy } \\
\text { hepatitis, renal failure, } \\
\text { fever }\end{array}$ & $\begin{array}{l}\text { positive in vitro sensitivity } \\
\text { for } \mathrm{pht}, \mathrm{cbz}, \mathrm{pb}\end{array}$ \\
\hline 34 & $+^{*}$ & $+*$ & & & + & & & + & & rash at 10 days with each \\
\hline 35 & $+*$ & + & & & & & & + & & diffuse urticaria at 5-7 days \\
\hline 36 & $+*$ & + & + & + & + & & & + & & \\
\hline 37 & + & $+^{*}$ & + & & + & + & vigabatrin & + & & \\
\hline 38 & $+*$ & + & & & & & & + & & rash at $7-10$ days \\
\hline 39 & + & $+^{*}$ & & & & + & & + & & \\
\hline
\end{tabular}


This study demonstrates a cross reaction rate of $40-58 \%$ between phenytoin and carbamazepine. A minority of the patients were under the care of the epilepsy clinic when the rashes occurred. Therefore the type of rash, severity, and the presence/absence of other features of a generalized hypersensitivity reaction, the interval between drug exposures, and the sequence of drug exposure could not always be accurately ascertained. However, the inclusion and exclusion criteria were sufficiently defined to allow an estimate of the cross reaction rate. This estimate is likely to be a conservative one because of the retrospective design, occurrence of rashes that were subtle and not requiring drug discontinuation, and some rashes that may occur beyond the 6 week cutoff from drug initiation.

In this study we could not address the issue of the relationship of initial dosage of AED to the likelihood of developing a rash. It has been suggested that rapid introduction (or high initial drug concentrations) of phenytoin, carbamazepine, and lamotrigine ${ }^{1.18}$ increase the risk of a skin rash. An additional consideration might be a "priming" effect induced by a reaction to the first AED. For example, some patients in our study had their carbamazepine discontinued with the appearance of a rash and immediately had phenytoin introduced with a resulting second reaction. Conceivably the initial rash could "prime" the fundamental underlying mechanism(s) responsible for an idiosyncratic reaction and induce a second response that might not otherwise occur if introduction of the second drug were delayed or introduced very gradually. There have been reports of patients with an AED induced rash tolerating a slow reintroduction of the same drug. ${ }^{19-21}$

Although only 5 rashes from phenobarbital (2.4\% of exposures) were found, it was noted that $4 / 5$ of these patients experienced cross reactivity to carbamazepine and/or phenytoin. This observation might suggest that a history of phenobarbital sensitivity serves as a particularly sensitive indicator of patients predisposed to reactions from carbamazepine and/or phenytoin.

The mechanisms of allergic rash are not well understood. Some patients appear to have a genetically determined alteration in the enzymatic processes responsible for drug metabolism with the production of reactive metabolites..$^{17}$ Cell mediated immunologic processes may be involved; these two pathophysiologic processes are not mutually exclusive. ${ }^{9}$ Structural similarities between phenobarbital, phenytoin, carbamazepine, and primidone presumably account for some of mechanism(s) of cross reactivity.

Although allergic responses to AEDs have been recognized for years, there is a paucity of data to assist the clinician in selecting an alternate AED if the patient develops a rash or additional features of the generalized hypersensitivity syndrome. Shear and Spielberg ${ }^{12}$ studied the responses of lymphocytes (from patients with clinical AED hypersensitivity reactions) to drug metabolites generated by a murine hepatic microsomal system. In their 53 patients 13 had clinical hypersensitivity reactions to carbamazepine and phenytoin. Of those exposed to both carbamazepine and phenytoin, 15 were sensitive to phenytoin and 14 were sensitive to carbamazepine. Therefore, in contrast to our study, 13/15 (86\%) of their subjects sensitive to phenytoin were sensitive to carbamazepine and $13 / 14(90 \%)$ subjects sensitive to carbamazepine were sensitive to phenytoin. These figures are probably higher than most clinicians' experience and likely can be attributed to selection factors involving the type of patients studied (20/53 patients had skin rash alone with almost all of the remaining patients having experienced a multisystem hypersensitivity reaction).

Pelekanos et al. ${ }^{10}$ described the clinical features of skin rash from AEDs in a pediatric population. They reported 50 patients of whom 10 had sensitivity reactions from 2 AEDs and 4 patients with reactions to $3 \mathrm{AEDs}$; all patients with reactions to 2 or more AEDs involved phenytoin, carbamazepine, or phenobarbital. Among the 14 patients with multiple sensitivities, the severity of subsequent skin reaction was the same in 9 cases, more severe in 2 cases, and less severe in 3 cases.

We encountered no cutaneous reactions from valproic acid. Results from recent clinical trials support this drug's spectrum of efficacy against partial and generalized seizures. ${ }^{2,6,22}$ Therefore, in general, we favour the use of valproic acid as an appropriate "next" treatment for patients experiencing a rash from any other AED. Other considerations might be a benzodiazepine (such as clobazam) or one of the other new AEDs with a low proclivity for producing rashes (gabapentin, vigabatrin). ${ }^{23.24}$

\section{ACKNOWLEDGEMENTS}

The authors gratefully acknowledge Dr. Stephen Phillips for statistical advice and reviewing the manuscript. We also thank Mrs. Marlyn Purdy for expert secretarial assistance.

\section{REFERENCES}

1. Chadwick D, Shaw MBM, Foy P, Rawlins MD, Turnbull DM. Serum anticonvulsant concentrations and the risk of drug induced skin eruptions. J Neurol Neurosurg Psychiatry 1984; 47: 642-644.

2. Richens A, Davidson DL, Cartlidge NE, Easter DJ. A multicentre comparative trial of sodium valproate and carbamazepine in adult onset epilepsy. J Neurol Neurosurg Psychiatry 1994; 57: 682-687.

3. Brodie MJ, Richens A, Yuen AWC. Double-blind comparison of lamotrigine and carbamazepine in newly diagnosed epilepsy. Lancet $1995 ; 345: 476-479$.

4. Sillanpaa M. Carbamazepine: pharmacology and clinical uses. Acta Neurol Scand 1981; 64 (Suppl. 88): 1-102.

5. Kramlinger KG, Phillips KA, Post RM. Rash complicating carbamazepine therapy. J Clin Psychopharmacol 1994; 14: 408-413.

6. Mattson RH, Cramer J, Collins JF. A comparison of valproate with carbamazepine for the treatment of complex partial seizures and secondarily generalized tonic-clonic seizures in adults. $\mathrm{N} \mathrm{Engl} \mathrm{J}$ Med 1992; 327: 765-771.

7. Knutsen AP, Anderson J, Satayaviboon S, Slavin RG. Immunologic aspects of phenobarbital hypersensitivity. J Pediatr 1984; 105: 558-563.

8. Dreifuss FE, Langer DH. Side effects of valproate. Am J Med 1988; 84 (Suppl. 1): 34-41.

9. Roujeau JC, Sterns RS. Severe adverse cutaneous reactions to drugs. N Engl J Med 1994; 331: 1272-1278.

10. Pelekanos J, Camfield P, Camfield C, Gordon K. Allergic rash due to antiepileptic drugs: clinical features and management. Epilepsia 1991; 32: 544-559.

11. Dean AG, Dean JA, Burton AH, Dicker RC. Epi Info: a general purpose microcomputer program for public health information systems. Am J Prev Med 1991; 7: 178-182.

12. Shear N, Spielberg SP. Anticonvulsant hypersensitivity syndrome. In vitro assessment of risk. J Clin Invest 1988; 82: 1826-1832.

13. Kahn HD, Faguet GB, Agee JF, Middleton HM. Drug induced liver injury. In vitro demonstration of hypersensitivity to both phenytoin and phenobarbital. Arch Intern Med 1984; 144: 1677-1679.

14. Goldstein N, Leider M, Baer R. Drug eruptions from anticonvulsant drugs. Arch Dermatol 1963; 87: 612-617.

15. Reents SB, Luginbuhl WE, Davis SM. Phenytoin-carbamazepine cross-sensitivity. DICP 1989; 23: 235-236. 
16. Pirmohamed M, Graham A, Roberts P, et al. Carbamazepine-hypersensitivity: assessment of clinical and in vitro chemical cross reactivity with phenytoin and oxcarbazepine. $\mathrm{Br} \mathrm{J}$ Pharmac 1991; 32: 741-749.

17. Chang DKM, Shear NH. Cutaneous reactions to anticonvulsants. Semin Neurol 1992; 12: 329-337.

18. Richens A. Safety of lamotrigine. Epilepsia 1994; 35 (Suppl. 5): S37-S40.

19. Smith H, Newton R. Adverse reactions to carbamazepine managed by desensitization (Letter). Lancet 1985; 1: 753.
20. Eames P. Adverse reactions to carbamazepine managed by desensitization (Letter) Lancet $1989 ; 1: 509-510$

21. Tavernor SJ, Wong IC, Newton R, Brown SW. Rechallenge with lamotrigine after initial rash. Seizure 1995; 4: 67-71.

22. Heller AJ, Chesterman P, Elwes RDC, et al. Phenobarbitone, phenytoin, carbamazepine, or sodium valproate for newly diagnosed adult epilepsy: a randomised comparative monotherapy trial. J Neurol Neurosurg Psychiatry 1995; 58: 44-50.

23. Mclean MJ. Gabapentin. Epilepsia 1995; 36 (Suppl. 2): S73-S86.

24. Ben-Menachem E. Vigabatrin. Epilepsia 1995; 36 (Suppl. 2): S95S104. 